\title{
MUNICIPAL SOLID WASTE IN GOIÁS (BRAZIL): CURRENT SCENARIO AND PROJECTIONS FOR THE FUTURE
}

\author{
Diogo Appel Colvero ${ }^{1,2 *}$, Ana Paula Duarte Gomes ${ }^{1}$, Luís António da Cruz Tarelho ${ }^{1}$, Manuel ARlindo Amador \\ DE MATOS ${ }^{1}$
}

1 Universidade de Aveiro, Departamento de Ambiente e Ordenamento (Department of Environment and Planning), Campus Universitário de Santiago, 3810-193 Aveiro, Portugal.diogocolvero@ua.pt,pgomes@ua.pt, 1tarelho@ua.pt, amatos@ua.pt

2 Researcher of Brazilian National Council for Scientific and Technological Development (CNPq), File No. 207172/2014-5

*CORRESPONDING AUTHOR, diogocolvero@ua.pt

Received on 02 November2017

Received in revised form on 03 November 2017

Accepted on 04 November2017

Editor: Maria Virginia Alves Martins, Universidade do Estado do Rio de Janeiro, Brazil

\section{Abstract}

The production of municipal solid waste (MSW) has increased annually worldwide. This situation can be verified in the municipalities of Brazil, that produce more MSW and have difficulty in managing their waste resulting in harmful consequences for the environment and ecosystems. For instance, in the State of Goiás, most of the produced MSW are sent to dumps. In this context, the goal of this study was to create a projection for the amount of MSW that will be generated in each of the 246 municipalities of Goiás by 2040. To do so, a population projection from 2015 to 2040 was done, alongside its correspondent MSW production and identification of the current MSW managing systems in the State. Results show that, by 2040, Goiás will have more than 8.7 million inhabitants, $32 \%$ more than 2015 . However, $88 \%$ of the municipalities will continue to have less than 50 thousand inhabitants. The municipalities of bigger dimension, on the other hand, will be concentrated mainly in

\section{Introduction}

The generation of municipal solid waste (MSW) in the world has been reaching increasingly alarming quantitative growth. In the year 2012, a survey of the World Bank (2012) shows that about 1.3 billion tonnes of MSW were produced at global levels, the equivalent of $1.2 \mathrm{~kg}$.inhab ${ }^{-1}$ day $^{-1} \mathrm{~kg}$ per inhabitant and per day). If this growth profile is maintained, it should reach 2.2 billion tonnes in 2025, the equivalent of $1.42 \mathrm{~kg} \cdot$ inhab $^{-1} \cdot \mathrm{day}^{-1}$ (World Bank, 2012). This is the consequence of the consumerism of the world population, and can lead to serious environmental problems (Lavee and Nardiya, 2013; Hannan et al., 2015).
Citation:

SCREENED BY

iThenticate

Colvero, D.A., Gomes, A.P.D., Tarelho, L.A.C., Matos, M.A.A., 2017. Municipal solid waste in Goiás (Brazil): current scenario and projections for the future. Journal of Sedimentary Environments, 2 (3): 236-249. the Goiânia Metropolitan area and surroundings of the Federal District regions. In terms of MSW production, an increase of about $35 \%$ in waste generation is estimated for 2040 when compared to 2015. In 2040, the Goiânia Metropolitan, surroundings of the Federal District and the Southwest regions of Goiás will produce $70 \%$ of the State MSW. Regarding the produced MSW technological routes, in 2015 about $70 \%$ of the State waste went to either unlicensed landfills or dumps, while $8 \%$ did not even get collected, having ended up in wastelands or waterways. Considering this panorama in Goiás, what will be the management of MSW in 2040 if nothing is done?

Keywords: Municipal solid waste. Generation. Projections. Goiás. Developing countries.
In addition to the quantity of produced MSW, another issue that concerns the society is the poor management of these wastes. Even though there are integrated systems for the treatment of such wastes to be operated in good condition, namely by biological treatment, thermal treatment, recycling and landfill (Kontos et al., 2005), in developing countries there is a deficiency in the provision of services throughout the whole waste management chain, from collection to final disposal.

In developing countries, programs to prevent the production of waste are scarce, as are the incentives to 
increase the lifespan of materials. In Brazil, despite Law $\mathrm{N}^{\circ}$. 12305 (National Policy of Solid Waste) establishing the principles of the prevention and life cycle of products, the circular economy is still an incipient practice. It can be seen that there are practically no actions aimed at reducing waste production, such as initiatives to change people consumption patterns, or information about the life-cycle impacts and the costs of the use of resources (Brazil, 2010; EC, 2011; Godecke et al., 2013). This information gap is translated into inadequate management of the MSW, and results in mixed residues, deposited in landfills or even in dumps (Abreu et al., 2016; Figueiredo, 2012). Another complicating element in the management of MSW in peripheral countries is the scarcity of economic resources, appropriate technologies and skilled labor to treat solid waste (Andrade and Ferreira, 2011).

An example of difficulties in MSW management occurs in the State of Goiás, Brazil. According to data of the Department of Environment, Water Resources, Infrastructure, Cities and Metropolitan Affairs SECIMA/GO, only 15 of 246 municipalities in the State have licensed landfills (SECIMA/GO, 2015). In these landfills, it is disposed the MSW of 16 municipalities of Goiás, because Cidade Ocidental shares its waste disposal system with Valparaíso de Goiás, neighboring municipality (Colvero et al., 2015). The remaining municipalities in the State send the produced MSW for unlicensed landfills and dumps.

Landfills are places where MSW are inadequately deposited without any kind of control over land use (Marchi, 2015). Since unlicensed landfills are MSW disposal sites, there are some mechanisms to minimize soil impacts, such as compaction of MSW, coverage of wastes with a soil layer, and in some cases, some monitoring to minimize groundwater pollution.

The final destination of MSW in unlicensed landfills and dumps that occur in Goiás municipalities can lead to contamination of soil and water resources, as well as putting human health at risk (Barros et al., 2015; Malakahmad et al., 2017).

In addition to the inadequate provisions, according to a survey conducted directly with the municipalities of Goiás (via questionnaires answered by municipal managers in 2012 and 2013, as noticed by Colvero et al. (2017), and concerning the implementation of MSW management services, waste collection is made by the city councils in $87 \%$ of municipalities of Goiás. The remaining 13\% were collected by a company contracted to carry out the service. Regarding the operation of the systems of final disposal of MSW, $95 \%$ of the municipalities manages this service directly, while others municipalities outsource this service to outside companies.

The change of this panorama of inefficient management of MSW of Goiás must begin by being based on a knowledge of the amounts of produced MSW. That way, it will be possible to establish which management system(s) is/are the most adequate and to define the most appropriate technologies to perform the treatment and recovery of the MSW (Assamoi and Lawryshyn, 2012).

\subsection{The main goals}

In this context, the objective of this study was to perform a quantitative projection of MSW generated by each municipality in Goiás until the year 2040. For this purpose, an estimation of the population evolution was carried out for these municipalities until 2040. The MSW management systems existing in Goiás were also identified.

\section{Study area}

Goiás is a state located in the Central-West region of Brazil. In 2015, the population was estimated at 6610681 inhabitants distributed in a territorial extension of $340111 \mathrm{~km}^{2}$, which corresponds to a population density of 19.4 inhabs. $\mathrm{km}^{-2}$.

State of Goiás borders at North with the State of Tocantins, to the East by the State of Bahia and the State of Minas Gerais, to the West with the State of Mato Grosso and at South with the State of Minas Gerais and Mato Grosso do Sul (Fig. 1). The State is divided into ten planning regions, which constitutes a strategic delimitation that aims to establish the investments of the state government according to the socio-economic needs of each region (IMB, 2014; IBGE, 2016 b, d).

\section{Material and methods}

The methods used to estimate the population and MSW produced in each municipality of Goiás, as well as the existing MSW management systems in the State (and material flow), are described in the following sections.

\subsection{Methods of population projection}

To estimate the quantity of MSW that are generated in a given future year, it is necessary to perform a population projection. The population estimation can be determined through the use of mathematical models or statistical regression analysis methods (linear or non-linear). The regression methods are applied, when large historical series of data is available, while the mathematical models are used when information is scarce, as for example, the population of demographic census in three or four specific years (Benetti, 2007).

Because the official population data of each of the 246 municipalities of Goiás are listed in the censuses carried out by the Brazilian Institute of Geography and Statistics - IBGE (DATASUS, 2016 a, b) for the years 1980, 1991, 2000 and 2010, we decided to apply mathematical methods, which will be described in the following items. 


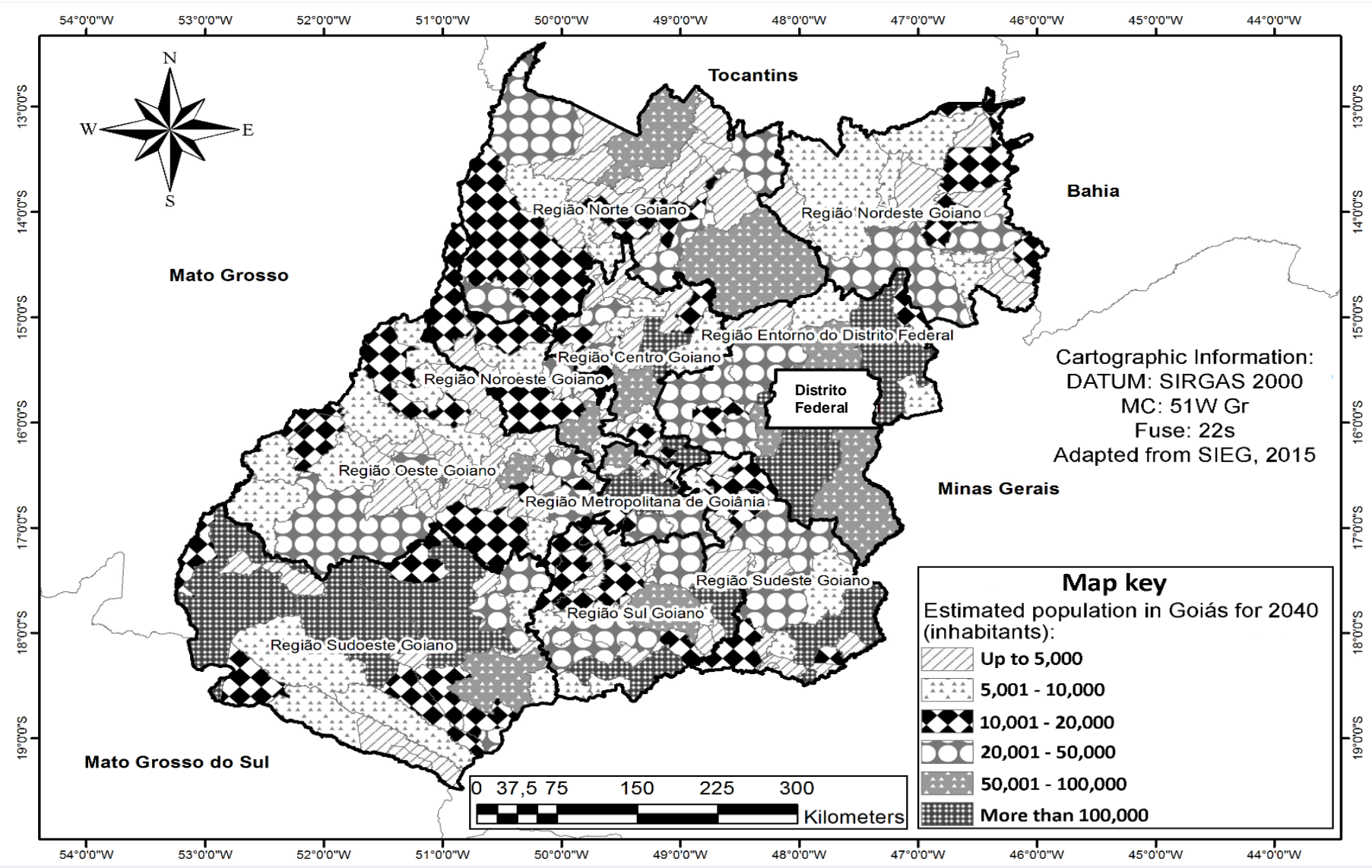

Fig. 1. Quantitative population in the municipalities of Goias in 2040.

In this study, the population projection of Goiás municipalities was performed for 2040. It was established for the project horizon the year 2040, because the Law N $N^{\circ} .12$ 305 stablished that the National Solid Waste Plan must have a time horizon of 20 years (Brazil, 2010 b). Based on the assumption that in 2020 the State may have a MSW management system appropriate and ready to operate, the population of the endof-life of this system will be estimated for 2040.

\subsubsection{Arithmetic Projection Method}

According to Benetti (2007), the arithmetic projection method is applied in situations where population growth occurs at a constant rate over time, taking as a reference the population at the starting date and without periodic accretion. The model considers an evolution in arithmetic progression, being considered a reliable method in short term estimatoins. The calculations for this method are those presented in Equation 1 (Qasim, 1999; Marques and Sousa, 2008),

$$
P_{t_{a}}=P_{o}+K_{a} \cdot\left(t-t_{0}\right)
$$

where: $P_{t_{a}}=$ Estimated population, by the arithmetic method, in year $t$ (inhabitants); $P_{0}=$ Population in year $t_{0}$ (inhabitants); $K_{a}=$ arithmetic growth coefficient; $t_{0}=$ date of the first available census (year) and; $t=$ date on which the population is to be estimated.

The population growth rate as a function of time can be calculated as: $\frac{\mathrm{dP}}{\mathrm{dt}}=\mathrm{K}_{\mathrm{a}}$. However, the $K_{a}$ coefficient was calculated according to Equation 2:

$$
K_{a}=\frac{P_{n}-P_{0}}{t_{n}-t_{0}}
$$

where: $P_{n}=$ Population in the last year of census; $P_{0}=$ Population in the first year of census; $t_{n}=$ year of last census; $t_{0}=$ year of the first census.

\subsubsection{Geometric Projection Method}

A widely used methodology for estimating population at any time $t$ is through the mean rate of population growth $(r)$ between two known periods (Rios-Neto and Riani, 2004), for which the population is known. In geometric projection, population growth is a function of the population that exists at each moment (Benetti, 2007). 
Arithmetic projection, is more a reliable method in shortterm estimates. Thus, we can calculate the geometric or exponential growth rate, according to equations 3 and 4, respectively (Qasim, 1999; Marques and Sousa, 2008),

$$
\begin{aligned}
& r_{g}=\left(\sqrt[\Delta t]{\frac{P_{n}}{P_{0}}}\right)-1 \\
& r_{e}=\frac{1}{\Delta t} \cdot \ln \left(\frac{P_{n}}{P_{0}}\right)
\end{aligned}
$$

With values of the growth rate, it is possible to calculate the geometric and exponential population, in any year $t$, using equations 5 and 6 , respectively,

$$
\begin{aligned}
& P_{t_{g}}=P_{0} \cdot\left(1+r_{g}\right)^{\left(t-t_{0}\right)} \\
& P_{t_{e}}=P_{0} \cdot e^{r_{e}\left(t-t_{0}\right)}
\end{aligned}
$$

where: $P_{t_{g}}=$ population estimated by the geometric method, at date $t$ (inhabitants); $P_{t_{e}}=$ population estimated by the exponential method, in date $t$ (inhabitants), $t_{0}=$ date of the first available census (year) and $t=$ date in which the population is to be estimated (year).

\subsubsection{Decreasing rate of growth method}

In the decreasing rate of growth method, the following premise is used: as the population of a municipality grows, the rate of growth of the population decreases. In other words, the population tends asymptotically to a saturation value (Benetti, 2007). The model of population projection using this method is translated into the Equation 7 (Qasim, 1999; Marques and Sousa, 2008),

$$
P_{t_{d}}=P_{0}+\left(P_{s}-P_{0}\right)\left[1-e^{-K_{d} \cdot\left(t-t_{0}\right)}\right]
$$

where:

$P_{t_{d}}=$ Estimated population, by the decreasing rate method, in year $t$ (inhabitants); $P_{0}=$ Population in year $\mathrm{t}_{0}$ (inhabitants); $P_{S}=$ Population of saturation (inhabitants); $K_{d}=$ coefficient of decreasing rate of growth; $t_{0}=$ date of the first available census (year) and; $t=$ date on which it is intended to estimate the population (year).

The population growth rate as a function of time is given by: $\frac{\mathrm{dP}}{\mathrm{dt}}=\mathrm{K}_{\mathrm{d}} \cdot\left(\mathrm{P}_{\mathrm{S}}-\mathrm{P}\right)$.

The saturation population and the coefficient $K d$ were calculated according to Equations 8 and 9,

$$
P_{S}=\frac{2 \cdot P_{0} \cdot P_{1} \cdot P_{2}-P_{1}^{2} \cdot\left(P_{0}+P_{2}\right)}{P_{0} \cdot P_{2}-P_{1}^{2}}
$$

$K_{d}=\frac{-\ln \left[\left(P_{s}-P_{2}\right) /\left(P_{s}-P_{1}\right)\right]}{t_{2}-t_{1}}$

where: $P_{0}, P_{1}$ and $P_{2}=$ population in the years of censuse $\mathrm{t}_{0}$ $t_{1}, t_{2} ; t_{0}, t_{1}, t_{2}=$ periods of time equidistant from each other.

It should be emphasized that there are other methods of population projection such as logistic growth and multiplicative regression. However, the three methods described in sections 3.1.1, 3.1.2 and 3.1.3 can be considered the best ones to estimate the population growth trend of the municipalities of Goiás.

\subsection{Estimations of the municipal solid waste quantitative generated in Goiás}

In order to forecast the MSW quantity that will be generated in Goiás in 2040, two sets of information were used: i) the population estimation for each Goiás municipality (number of inhabitants), obtained from the methodology described in section 3.1, and ii) generation per capita of MSW for each municipality of Goiás (in kg.inhab ${ }^{-1}$.day ${ }^{1}$ ), according to Colvero et al. (2017).

The generation per capita of MSW for each municipality of Goiás was defined based on two sets of information (Colvero et al., 2017): i) based on primary data from the questionnaire answered by the municipalities of Goiás in 2012 and 2013, and ii) data obtained from literature about studies carried out in Goiás municipalities with different numbers of inhabitants (Table 1). The generation per capita of MSW was arranged by population ranges (Colvero et al., 2017), according to Table 1.

Based on the two sets of information established for the generation per capita of MSW, two scenarios were defined for the projection of MSW generation in each municipality of Goiás:

Scenario 1: population estimation for each Goiás municipality (number of inhabitants) multiplied by the values of generation per capita of MSW resulting from the questionnaire sent to the municipalities of Goiás;

Scenario 2: population estimation for each municipality in Goiás (number of inhabitants), multiplied by the values of generation per capita of MSW obtained in the literature.

As a result of the application of this methodology to the 246 municipalities of the State, two estimations of MSW generation were obtained for each municipality and, consequently, for each of the two scenarios considered for Goiás. Generation per capita of MSW (Colvero et al., 2015), means that the production of MSW will vary over time only according to the population variation (ARCADIS and EUNOMIA, 2009; BNDES, 2013 a).

In the case of scenario 1 , since the generation per capita of MSW is considered constant (Colvero et al., 2015), means that MSW production will vary over time only according to 
population variation (ARCADIS and EUNOMIA, 2009; BNDES, 2013 a).

As in Goiás there are municipalities that will have a population growth and others a population decrease, the generation of MSW will be variable according to the population growth/decrease rate over the years.

In the case of scenario 2, the MSW production projection depends on two factors: i) population growth (or decrease), and ii) alteration of the category of the population range of each municipality, with consequent change of its generation per capita of MSW (Table 1).
This methodology was applied to obtain the following MSW generation estimations for the municipalities of Goiás:

- generation of MSW in the planning regions of Goiás in 2015, according to scenario 1;

- generation of MSW in the planning regions of Goiás in 2015 , according to scenario 2 ;

generation of MSW in the planning regions of Goiás in 2040, according to scenario 1;

- generation of MSW in the planning regions of Goiás in 2040 , according to scenario 2 .

Tab. 1. Estimation of the the generation per capita of MSW, by range of population, for Goiás. Adapted from Colvero et al. (2017).

\begin{tabular}{|c|c|c|}
\hline $\begin{array}{l}\text { Categories of the population } \\
\text { ranges for the municipalities of } \\
\text { Goiás (inhabitants) }\end{array}$ & $\begin{array}{c}\text { Median of generation per capita of MSW } \\
\text { - estimation for scenario } 1 \\
\left(\mathrm{~kg} . \text {.inhab }^{-1} \text {. }^{-1} \mathrm{yy}^{-1}\right)\end{array}$ & 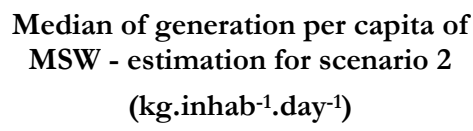 \\
\hline Up to 5000 & 0.90 & 0.46 \\
\hline From 5001 to 10000 & 0.87 & 0.50 \\
\hline From 10001 to 20000 & 0.95 & 0.54 \\
\hline From 20001 to 50000 & 0.86 & 0.60 \\
\hline From 50001 to 100000 & 0.77 & 0.69 \\
\hline More than 100000 & 0.85 & 0.77 \\
\hline
\end{tabular}

\subsection{MSW management systems in the State of Goias and its mass balance}

In order to calculate the MSW values for each treatment and final disposal technology in the State of Goiás it was necessary to identify which fraction of the population of the municipalities of Goiás is served by MSW collection systems. For this purpose, data from a survey carried out by IMB (2014) were used.

With the percentages of MSW collected in each municipality, the existing management systems for these wastes were identified, based on the information provided by the municipalities in response to the 2012/2013 SECIMA/GO questionnaires. This information was complemented with data from SECIMA/GO for 2015, which indicates the municipalities of Goiás that are sending the MSW to licensed landfills. In addition, the BNDES (2013b) information was used to identify the Goiás sorting centers. Based on the gathered information, it is concluded that the management of MSW in Goiás is done in the following locations: i) sorting centers; ii) a composting plant; iii) landfills licensed by SECIMA/GO; iv) landfills not licensed by SECIMA/GO and; v) dumps.

To calculate the quantities of MSW that are sent to the sorting centers (SC), BNDES (2012b) data were used. This study shows that in the municipalities of Goiás that have differentiated collection (DC) of recyclables, the value of this collection varies from $1 \%$ to $5 \%$ of the mass of the total
MSW generated. Thus, in this work we chose to use for the municipalities that have a destination for DC, a value of $3 \%$ of the MSW routed to the SC. However, $30 \%$ of the mass of MSW arriving in SC are eventually rejected and sent to dumps and landfills of the State of Goiás (NURSOL/UFG, 2014).

To estimate the quantities that are sent to the only composting plant in Goiás, as well as the tailings of this system, data available from BNDES (2012a) were used. The other MSW generated in Goiás have other destinations, such as licensed landfills, unlicensed landfills or dumps. There is also a fraction of MSW that is not collected and dumped into public roads and vacant lots (IMB, 2014). These destinations were identified according to SECIMA/GO (2015), BNDES (2013 b) and with the questionnaires answered by the municipalities.

In order to define the most appropriate MSW management system, the municipality, region or country must take into account the specificities of the generated MSW. In addition, it is necessary that these materials be analyzed through their production chain, considering from their generation (in terms of quantity), through the collection (differentiated or undifferentiated), transportation, the several forms of treatment and, to close the cycle, the elimination of these wastes (Pires et al., 2011).

This sequence of operations is designated in Brazil as the technological route of the MSW of a given location (BNDES, 
2013 b). In this context, the technological route of the MSW in Goiás and the quantity of MSW produced and treated in the State were analyzed using a fluxogram approach performed with STAN (C) software tool (version 2.5). This software alowed to calculate the general mass balance of MSW generated in the State.

\section{Results and Discussion}

\subsection{Population Projection of Goiás}

Until 1988, the State of Goiás had an area of $617831 \mathrm{~km}^{2}$ (IBGE, 2016 b, c). However, with the promulgation of the last Brazilian Constitution, on October 5, 1988, Goiás was divided into two states (Brazil, 1988): i) in the former northern Goiás state, the State of Tocantins was created, with 78 municipalities in Goiás (Rodrigues and Santos, 2015) and an area of $277721 \mathrm{~km}^{2}$ (IBGE, $2016 \mathrm{c}$ ), ii) the other $340111 \mathrm{~km}^{2}$ corresponding to 209 municipalities continued to belong to Goiás (Pereira et al., 2009). Latter, other localities were emancipated, until reaching the current 246 municipalities in the State of Goiás.

Despite the division of the state, along 30 years (from 1980 to 2010) the number of inhabitants of Goiás increased by $92 \%$, as shown in Table 2 .

Tab. 2. Quantitative population of the State of Goiás from 1980 to 2010, based on IBGE. Adapted from DATASUS, 2016 a, b).

\begin{tabular}{|l|c|c|c|c|}
\hline \multirow{2}{*}{ State } & \multicolumn{3}{|c|}{ Total population of Goiás, according to the demographic census (inhabitants) } \\
\cline { 2 - 4 } & 1980 & 1991 & 2000 & 2010 \\
\hline Goiás & 3121125 & 4018903 & 5003228 & 6003788 \\
\hline
\end{tabular}

To estimate the population of the municipalities of the State, in this work were considered only the inhabitants of the municipalities that continued to belong to Goiás after the creation of the State of Tocantins. Thus, based on the population projection models used in this study (section 3.1), calculations were made to estimate the population of Goiás from 2016 to 2040.

Of the 246 municipalities in Goiás was applyed: in 173 municipalities, the decreasing growth rate; in 69 municipalities the methodology of the geometric projection and; in other 4 municipalities the method of the arithmetic projection. These estimations were necessary because the IBGE has population projections for the entire State, but does not present a future population estimation for each municipality.

The estimated values in this work, following the described methodology, were compared with the quantitative population projected by the IBGE (2013) for the State of Goiás. The sum of the quantitative estimated population of each municipality of Goiás is close to the projected values by IBGE for the State. For example, for the year 2030, there is a population difference of only $0.2 \%$ between that estimated by IBGE and the one projected in this study; that is, IBGE estimates a population of 7712596 inhabitants by 2030, and in this study the projection is of 7727348 inhabitants.

Although the projections indicate larger population densities in the 2040 horizon (Fig. 1), the State wiil remain with most of the municipalities $(87.8 \%)$ classified as small, that is, with less than 50000 inhabitants (Araújo and Nunes, 2013). The regions with the highest number of municipalities with a population of more than 100000 inhabitants are the Entorno do Distrito Federal (EDF) and Metropolitana de Goiânia (MGyn), with 6 and 5 municipalities, respectively.

According to Souza (2011), this scenario occurs because the State has a productive profile, focused on monocultures, which leads to concentration of land and incomes and, consequently, generates economic inequality. Situation that stimulates urban agglomerations, as in the MGyn and EDF regions. In addition, SEGPLAN and SEPIN (2011), reported that in EDF there is a great population displacement coming from Brasília towards the municipalities of Goiás that are part of this region, a situation that is due to the high cost of living in the federal capital.

In addition, the quantitative population in each planning region can also be explained by the number of available jobs for each of the five sectors of activity (agriculture, trade, construction, industry and services). According to data from the IMB (2014), in all sectors, the State has 1439341 of jobs in 2012, concentrating more than 780000 jobs only in the MGyn region, which correspond to $54 \%$ of total employment in the State.

According to IBGE (2016 a), MGyn and EDF regions together hold about $55 \%$ of the State population (Table 3), with the MGyn region having the smallest territorial area of all regions and a density 17 times higher than the State average density. In opposite situation, it is the Nordeste Goiano, region that has 26 municipalities and a population of 184472 inhabitants. People are distributed in an area of 40 $181 \mathrm{~km}^{2}$, which means almost $12 \%$ of the area of the State and a population density of 4.59 inhabs. $\mathrm{km}^{-2}$, value four times 
smaller than the average density of the State (IBGE, 2015, 2016 d; IMB, 2014).

Population projections indicate that in 2040 the MGyn and EDF regions will continue to have the largest settlements. In addition to these regions, it is possible to join the Sudoeste Goiano that will reach more than 1.1 million inhabitants by 2040. Together, in 2040, these three regions (MGyn, EDF and Sudoeste Goiano) will have $66 \%$ of the population of Goiás. The state will increase from 6.6 million inhabitants in 2015 up to 8.7 million in 2040 (Table 3).

\subsection{Projection of solid urban waste production in the State of Goiás}

The obtained results suggest a scenario of growth of MSW production in the State of Goiás by 2040. According to the projections based on scenario 1 , the production of MSW in Goiás will increase from $5828 \mathrm{t}^{\mathrm{d} d a y^{-1}}$ (tons per day) in 2015 to 7764 t.day $^{-1}$ in 2040, representing an increase of $33 \%$. For scenario 2 , in the same period, the expected increase for the MSW generation will change from 4967 t.day $^{-1}$ in 2015 to 6849 t.day $^{-1}$ in 2040, meaning a growth of $38 \%$. So, the values projected for the production of MSW from scenario 1 are about 900 t.day ${ }^{-1}$ higher than the values estimated from scenario 2.

For both scenarios 1 and 2, the projections indicate that the MGyn and EDF are the regions with the highest MSW generation in Goiás. From the data of scenario 1, in 2015 these regions generated, together, 3056 t.day $^{-1}$ of MSW, the equivalent to $52.4 \%$ of the total produced MSW. In scenario 2 , in 2015 these two regions jointly generated 3073 t.day $^{-1}$ of MSW, a slightly larger quantity than that predicted according to scenario 1, but it represents $61.9 \%$ of the total generated MSW.

In addition, in both scenarios 1 and 2, the projections point to a growth in the quantity of MSW generated in the Sudoeste Goiano region. Based on the projections in scenario 1, in 2040 this region will assume the position of second largest MSW generator in Goiás, standing above the EDF in terms of MSW generation (Fig. 2 a).

Also, according to scenario 1, in 2040, the three regions (MGyn, EDF and Sudoeste Goiano) will produce about 4980 t.day $^{-1}$ of MSW, which means $64.1 \%$ of the total 7760 t.day $^{-1}$ of MSW that the State will generate. According to the projections for scenario 2, these three regions will produce about 4913 t.day ${ }^{1}$, which will represent $71.7 \%$ of the MSW generated in Goiás (Fig. 2 b).

Tab. 3. Demographic picture of ten planning regions of the State of Goiás. Adapted from IMB (2014), IBGE (2015, 2016 d) and DATASUS (2016 b). Legend: inhabs.km² = inhabitants per $\mathrm{km}^{2}$; Entorno do DF - Entorno do Distrito Federal; Metrop. Goiânia - Metropolitana de Goiânia.

\begin{tabular}{|c|c|c|c|c|c|}
\hline Region & $\begin{array}{c}\text { Number of } \\
\text { Municipalities }\end{array}$ & $\begin{array}{l}\text { Area } \\
\left(\mathrm{km}^{2}\right)\end{array}$ & $\begin{array}{c}\text { Population } 2015 \\
\text { Estimation of IBGE } \\
\text { (population) }\end{array}$ & $\begin{array}{l}\text { Population estimated for Goiás } \\
\text { by } 2040 \\
\text { (inhabitants) }\end{array}$ & $\begin{array}{c}\text { Demographic } \\
\text { density } \\
\left(\text { inhabs. } \mathrm{km}^{-2}\right)\end{array}$ \\
\hline Norte Goiano & 26 & 60946 & 320433 & 382508 & 5.3 \\
\hline Nordeste Goiano & 20 & 40181 & 184472 & 236901 & 4.6 \\
\hline Noroeste Goiano & 13 & 14872 & 147698 & 179567 & 9.9 \\
\hline Centro Goiano & 31 & 18536 & 675776 & 837589 & 36.5 \\
\hline Entorno do $D F$ & 19 & 30982 & 1179669 & 1416802 & 38.1 \\
\hline Oeste Goiano & 43 & 55535 & 352618 & 435547 & 6.4 \\
\hline Metrop. Goiânia & 20 & 7315 & 2421831 & 3185744 & 331.1 \\
\hline Sudeste Goiano & 22 & 25425 & 271226 & 389454 & 10.7 \\
\hline Sudoeste Goiano & 26 & 61499 & 622057 & 1109931 & 10.1 \\
\hline Sul Goiano & 26 & 24820 & 434901 & 526244 & 17.5 \\
\hline State of Goiás & 246 & 340111 & 6610681 & 8700287 & 19.4 \\
\hline
\end{tabular}



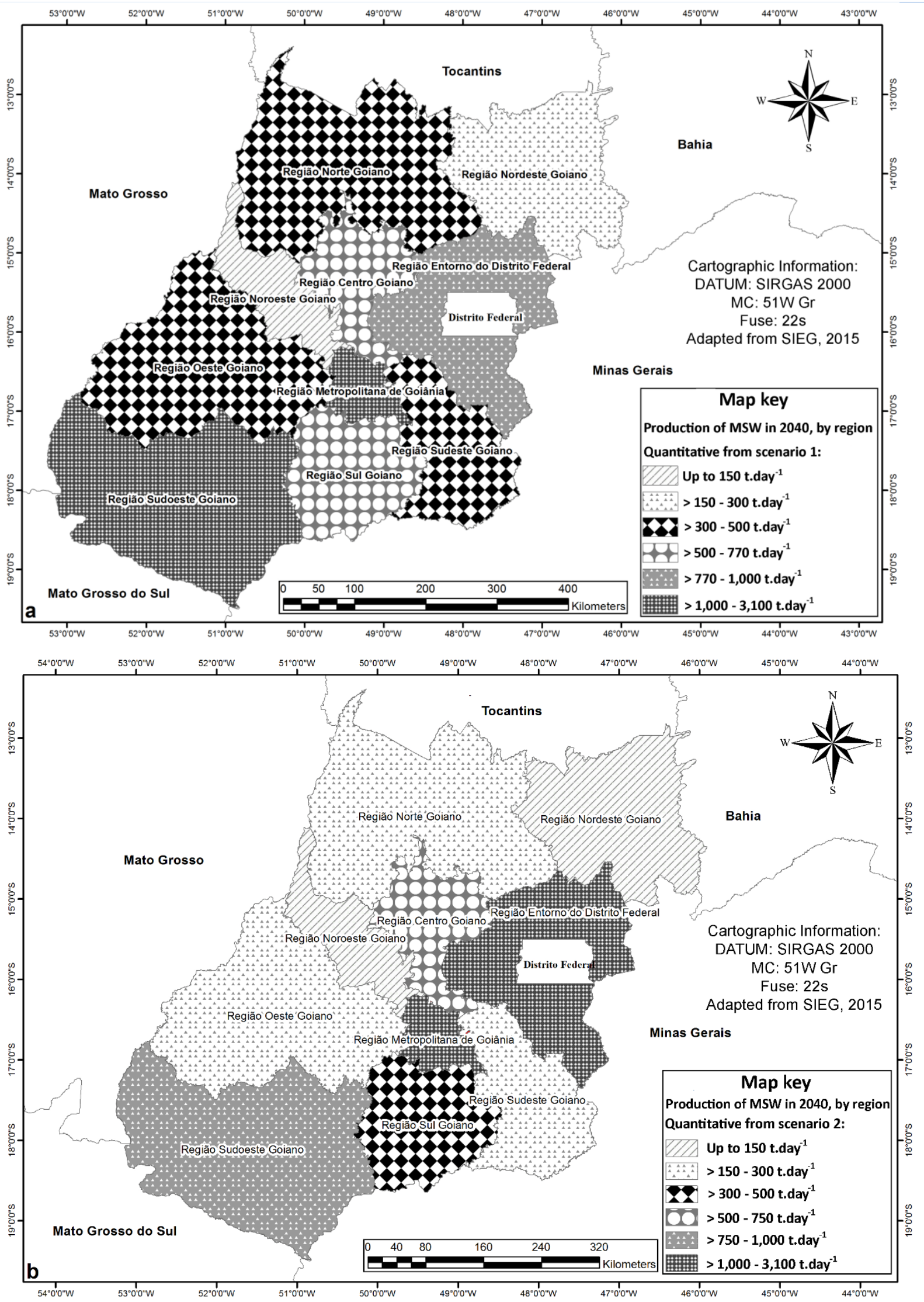

Fig. 2. Projections of urban solid waste production (t.day ${ }^{-1}$ ) based on scenarios 1 (a) and 2 (b), by planning region of the State of Goiás, in 2040 . 
In the opposite situation are the Noroeste Goiano and Nordeste Goiano, with the least generation of MSW, according to the projections for both scenarios 1 and 2 (in descending order of generation of waste are the Nordeste Goiano region and the Noroeste Goiano region) as shown in Figure 2 a, b. According to the projection of scenario 1, in 2015, these two regions together produced 287 t.day $^{-1}$ of MSW, equivalent to $4.9 \%$ of the total MSW of the State. While, according to the projections of scenario 2 , these regions produced 182 t.day $^{-1}$, or $3.7 \%$ of the total MSW generated in the State. Although, an increase in the generation of MSW is expected for 2040 in these two regions, these both regions together will continue to produce the smallest percentage of total MSW produced in the State, this is, $4.8 \%$ and $3.5 \%$, respectively, according to the projections of scenarios 1 and 2 for 2040.

\subsection{Mass balance of the technological route of urban solid waste in Goiás}

The MSW collection does not cover the entire population of Goiás (Table 4). According to IMB (2014), $92 \%$ of the MSW generated in 2013 were collected.

The municipalities of the MGyn region collected $99 \%$ of the generated MSW. However, there are regions with low collection rates, such as Noroeste and Norte Goiano, which collected about $80 \%$ of the generated MSW. The least satisfactory situation is observed in the Nordeste Goiano, where about $66 \%$ of MSW were collected.
RESEARCH PAPER

The main management routes of the MSW of the State are related to the undifferentiated collection of MSW and deposition in dumps and landfills, not licensed by SECIMA/GO. In fact, unlicensed dumps and landfills are the destination of $70 \%$ of the MSW produced in Goiás. Another part goes to the 15 landfills licensed by SECIMA/GO (2015), which received from $20 \%$ to $23 \%$ of MSW generated in the State. There are also between $7 \%$ and $9 \%$ of MSW that are not collected, and are abandoned in vacant lots, public roads and rivers (IMB, 2014).

In fact, less than $2 \%$ of MSW are detached and sent to sorting units, which can separate about $70 \%$ of the received MSW and send them for recycling. In the State, there is also a composting plant (BNDES, 2012a), which is installed in the municipality of Chapadão do Céu. The produced compost in this municipality unit is equivalent to less than $0.01 \%$ of the total mass of the produced MSW in the State.

The mass balance of the technological route of the produced MSW, in the State of Goiás, in 2015, is presented in Figures 3 and 4, for scenario 1 and scenario 2, respectively.

In Goiás, MSW management operations do not integrate technologies that use another form of biological treatment than composting; for example, the anaerobic digestion technology of the biodegradable organic fraction and subsequent energy recovery of the produced biogas, has not been the choice of Decision-makers for the MSW Management.

Tab. 4. Overview of the MSW collection, by planning region of Goiás in the year 2015. Legend: t.day ${ }^{-1}=$ tons per day; Entorno do DF Entorno do Distrito Federal; Metrop. Goiânia - Metropolitana de Goiânia;

\begin{tabular}{|c|c|c|c|c|c|c|}
\hline \multirow[t]{3}{*}{ Planning regions } & \multicolumn{2}{|c|}{ Produced MSW } & \multicolumn{4}{|c|}{ Colleted MSW } \\
\hline & \multirow{2}{*}{$\begin{array}{c}\text { Scenario } 1 \\
\text { t.day }^{-1}\end{array}$} & \multirow{2}{*}{$\begin{array}{c}\text { Scenario } 2 \\
\text { t.day }^{-1}\end{array}$} & \multicolumn{2}{|c|}{ Scenario 1} & \multicolumn{2}{|c|}{ Scenario 2} \\
\hline & & & t.day ${ }^{-1}$ & collected $\%$ & t.day $^{-1}$ & collected $\%$ \\
\hline Norte Goiano & 319 & 184 & 242 & 75.9 & 147 & 79.9 \\
\hline Nordeste Goiano & 173 & 99 & 112 & 64.7 & 67 & 67.1 \\
\hline Noroeste Goiano & 114 & 83 & 90 & 79.3 & 66 & 78.8 \\
\hline Centro Goiano & 606 & 488 & 550 & 90.9 & 455 & 93.3 \\
\hline Entorno do DF & 793 & 843 & 706 & 89.0 & 760 & 90.2 \\
\hline Oeste Goiano & 324 & 190 & 261 & 80.4 & 154 & 81.0 \\
\hline Metrop. Goiânia & 2262 & 2230 & 2229 & 98.5 & 2208 & 99.0 \\
\hline Sudeste Goiano & 268 & 164 & 234 & 87.2 & 143 & 87.1 \\
\hline Sudoeste Goiano & 562 & 416 & 508 & 90.4 & 378 & 91.0 \\
\hline Sul Goiano & 407 & 270 & 373 & 91.6 & 248 & 91.9 \\
\hline Total & 5828 & 4967 & 5305 & 91.0 & 4626 & 93.1 \\
\hline
\end{tabular}




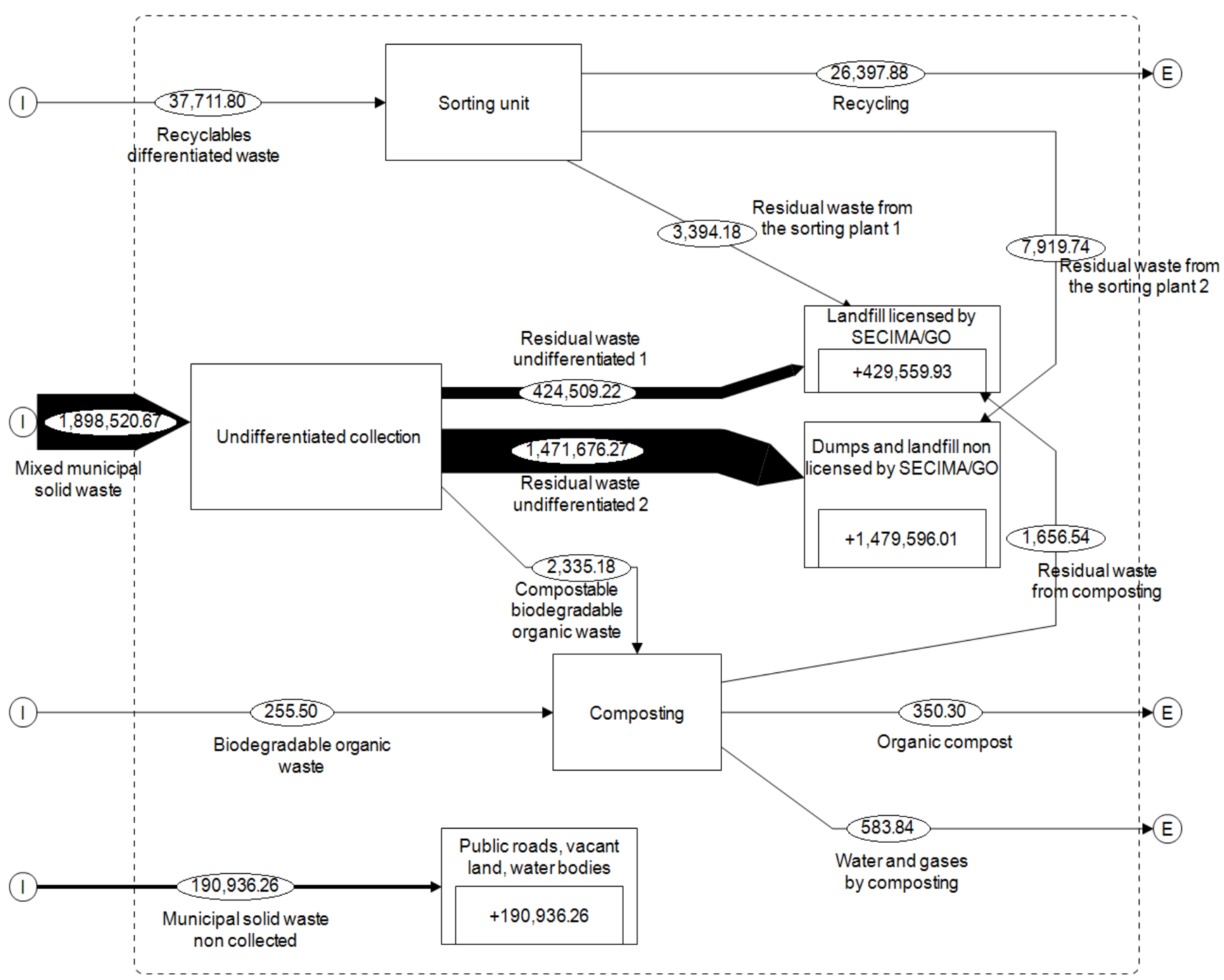

MFA-RU de Goias_2015, 2016

Fig. 3. Technological route of solid urban waste produced (in t.year ${ }^{-1}$ ) in the State of Goiás in 2015, according to the projections for scenario 1.

Management systems for the thermal treatment of MSW, such as incineration (Kontos et al., 2005), also do not exist in the municipalities of Goiás. It is also observed that even in cases where MSW are destined for landfills, that is one of the least sustainable options for the management of MSW (Cherubini et al., 2009), there is no energy recovery of produced biogas.

Goiás has a gap in terms of evaluation that encompasses not only the financial aspects but also the technical, environmental, legislative and social aspects of management policies of MSW, a situation characteristic of developing countries (Guerrero et al., 2013).
Decision-makers should define an MSW management system according to the specificities of the region, which includes in addition to technological and financial aspects the involvement of the populations (Feo and Malvano, 2009).

The additional 340 t.day ${ }^{-1}$ of non-collected MSW, as well as the 3429 t.day $^{-1}$ of MSW that are destined for unlicensed landfills and dumps in the municipalities of Goiás (quantitative shown in Fig. 3) may be contaminating soil, surface and underground water bodies, as well as causing diseases to the animals and people that are in contact with these residues (Barros et al., 2015; Marchi, 2015). 


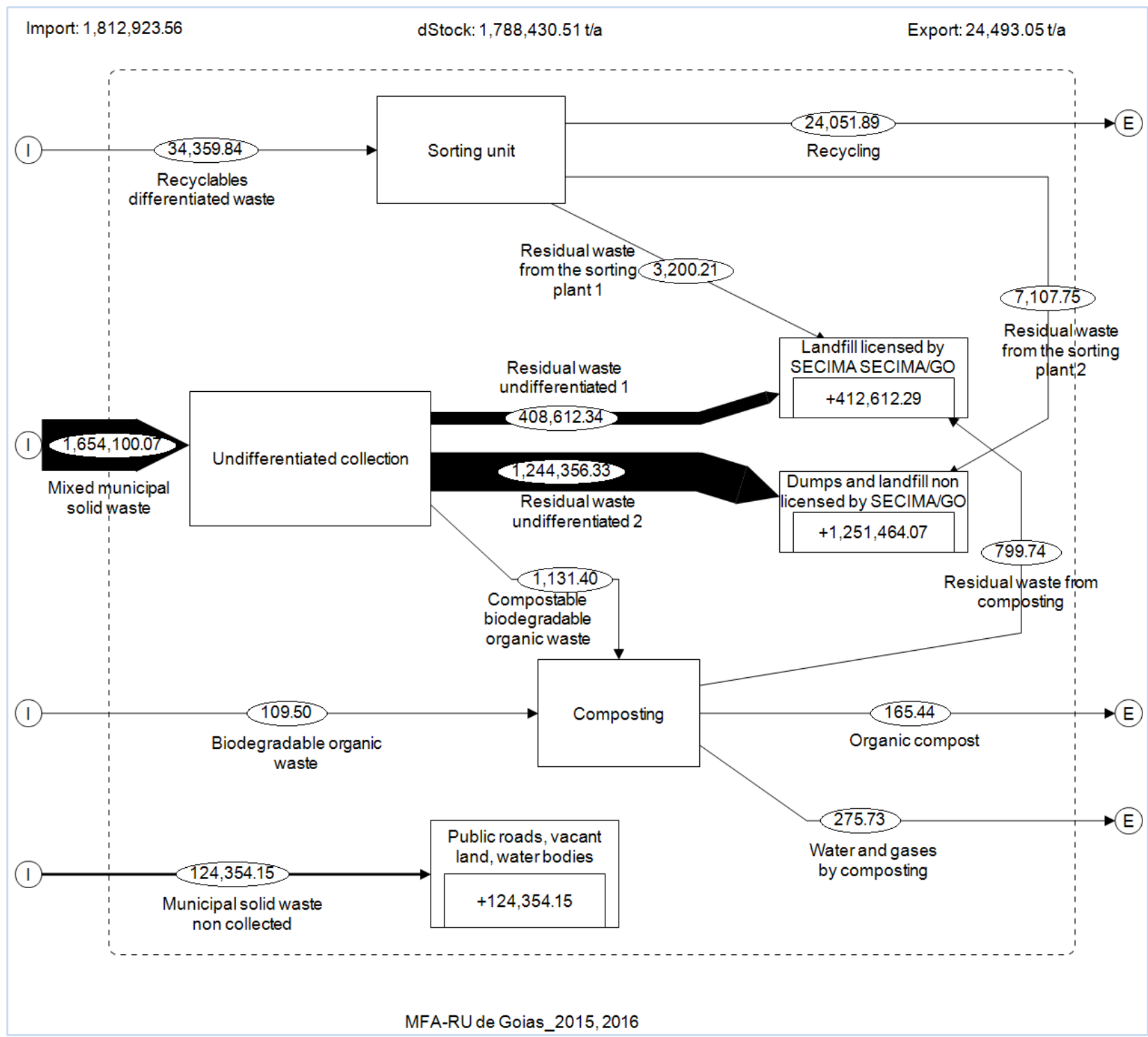

Fig. 4. Technological route of solid urban waste produced (in t.year ${ }^{-1}$ ) in the State of Goiás in 2015, according to the projections for scenario 2.

According to a study performed by Malakahmad et al. (2017), one ton of MSW deposited in a landfill produces $0.188 \mathrm{~m}^{3}$ of leachate; hundreds of cubic meters of this liquid may be percolating and contaminating daily the soil and waters of the municipalities of the State of Goiás.

In addition, there is the landfill gas (LFG), resulting from aerobic and anaerobic biological decomposition of organic residues in MSW (Malakahmad et al., 2017). In the present study, the LFG is composed of $45-60 \%$ of $\mathrm{CH}_{4}$ and $40-60 \%$ of $\mathrm{CO}_{2}$ (Tchobanoglous et al., 1993), which are two of the main greenhouse gases (Piñas et al., 2016).

\section{Conclusion}

According to population projections for the 246 municipalities in Goiás, the State will increase from 6.6 million of inhabitants in 2015 to a population exding 8.7 million of inhabitants in 2040. The State will increase from the current 12 to 19 municipalities with more than 100 thousand inhabitants in 2040, being the most part of population (55\%) located in MGyn and EDF. MGyn has a population density of 331.1 inhabs. $\mathrm{km}^{-2}$, well above the average of Goiás.

With regard to projections for the production of municipal solid waste, there will be an increase ranging from $33 \%$ to $38 \%$ in the generation of this kind of waste in Goiás by 2040 . From more than 6500 t.day $^{-1}$ (up to 7800 t.day $^{-1}$ ) of MSW that will be produced in that year, between $64 \%$ and $72 \%$ will be generated in three of the ten planning regions, MGyn, Sudoeste Goiano and EDF. Opposite situation will be observed in the Noroeste Goiano and Nordeste Goiano, which will produce between $3.8 \%$ and $4.5 \%$ of MSW of Goiás. However, the greatest problem is not the quantity of MSW 
that the municipalities of Goias will produce, but rather the lack of adequate management of this waste.

Few municipalities have MSW treatment and disposal systems. In the State of Goiás there are 15 landfills (licensed by SECIMA/GO), 22 sorting centers and a composting plant. In contrast, 220 systems of inadequate MSW disposal were identified, with only 43 of such systems in the Centro Goiano.

This situation evidences the urgent need for the creation of new systems of treatment and final disposal of MSW, considering that in 2015 between $76 \%$ and $79 \%$ of the total produced MSW in Goiás were discarded inadequately. This scenario will aggravate year after year, as more waste will be produced.

Faced with this alarming panorama of the increasing production of MSW and the lack of an adequate system for the management of this waste, Goiás needs to create a strategy for alternatives to treat and dispose the MSW in an environmentally adequate way.

\section{Acknowledgment}

The authors gratefully acknowledge the Brazilian National Council for Scientific and Technological Development (CNPq).

\section{References}

Abreu, A.E.S., Gandolfo, O.C.B., Vilar, O.M., 2016. Characterizing a Brazilian sanitary landfill using geophysical seismic techniques. Waste Management, 53, 116-127. doi.org/10.1016/j.wasman.2016.03.048

Andrade, R.M. de, Ferreira, J.A., 2011. A gestão de resíduos sólidos urbanos no Brasil frente às questões da globalização. REDE - Revista Eletrônica do Prodema, 6(1), 7-22. Retrieved from http://www.revistarede.ufc.br/revista/index.php/rede/arti cle/viewArticle/118

Araújo, F.T.V., Nunes, A.B.A., 2013. A política nacional de resíduos sólidos, a meta de eliminação dos lixões e os desdobramentos nos estados brasileiros. In: XXVII Congresso Brasileiro de Engenharia Sanitária e Ambiental, Rio de Janeiro, RJ, Associação Brasileira de Engenharia Sanitária e Ambiental - ABES.

ARCADIS - Infrastructure, Environment, F., \& EUNOMIA Research \& Consulting, 2009. Assessment of the options to improve the management of bio-waste in the European Union. Retrieved from http://ec.europa.eu/environment/waste/compost/pdf/ia_ biowaste - final report.pdf

Assamoi, B., Lawryshyn, Y., 2012. The environmental comparison of landfilling vs. incineration of MSW accounting for waste diversion. Waste Management, 32(5), 1019-1030. doi.org/10.1016/j.wasman. 2011.10.023

Barros, R.G., Days, P.P., Araújo, V.K.A., 2015. Investigação de passivo ambiental na área do aterro sanitário de Hidrolânday,
GO. Revista Elettrônica Em Gestão Educação E Tecnologia Ambiental, 19(3), 73-82. doi.org/105902/2236117018948

Benetti, J.K., 2007. A utilização da projeção populacional na elaboração de projetos de saneamento básico: estudo de caso, Ijuí, RS (Monograph). Universidade Regional do Noroeste do Estado do Rio Grande do Sul.

BNDES - Banco Nacional de Desenvolvimento Econômico e Social, 2012 a. Produto 5: Núcleo Centro Oeste. Análise das diversas tecnologias de tratamento e disposição final de resíduos sólidos no Brasil, Europa, Estados Unidos e Japão. Recife: FADE

BNDES - Banco Nacional de Desenvolvimento Econômico e Social, 2012 b. Produto 7: Relatório final sobre as principais rotas tecnológicas de destinação de resíduos sólidos urbanos no Exterior e no Brasil. Análise das Diversas Tecnologias de Tratamento e Disposição Final de Resíduos Sólidos Urbanos no Brasil, Europa, Estados Unidos e Japão. Recife: FADE.

BNDES - Banco Nacional de Desenvolvimento Econômico e Social. 2013 a. Produto 10: Relatório final de avaliação técnica, econômica e ambiental das técnicas de tratamento e destinação final dos resíduos. Jaboatão dos Guararapes.

BNDES - Banco Nacional de Desenvolvimento Econômico e Social, 2013 b. Produto 11: Análise das diversas tecnologias de tratamento e disposição final de resíduos sólidos urbanos no Brasil, Europa, Estados Unidos e Japão. Jaboatão dos Guararapes.

Brasil, Constituição da República Federativa do Brasil, 1988. Presidência da República. Casa Civil. Subchefia de assuntos jurídicos. 35a edição. 2012. Biblioteca digital da Câmara dos deputados. Centro de documentação e informação. Coordenação de biblioteca (1988). Brasil.

Brasil, Lei No. 12305, de 2 de agosto, 2010. Brasília, DF: Institui a Política Nacional de Resíduos Sólidos; altera a Lei No. 9605, de 12 de fevereiro de 1998; e dá outras providências. Retrieved from http://www.planalto.gov.br/ccivil_03/ _ato2007-2010/2010/lei/112305.htm

Cherubini, F., Bargigli, S., Ulgiati, S., 2009. Life cycle assessment (LCA) of waste management strategies: Landfilling, sorting plant and incineration. Energy, 34(12), 2116-2123. doi.org/10.1016/j.energy. 2008.08.023

Colvero, D.A., Carvalho, E.H. de, Pfeiffer, S.C., Gomes, A.P., 2017. Avaliação da geração de resíduos sólidos urbanos no Estado de Goiás, Brasil: análise estatística de dados. Revista Engenharia Sanitária E Ambiental - RESA. doi.org/10.1590/S1413-41522017159448

Colvero, D.A., Gomes, A.P.D., Pfeiffer, S.C., 2015. Análise dos custos das rotas tecnológicas dos resíduos sólidos urbanos de Cidade Ocidental, Goiás. Sodebrás, 10(117), 196-204. Retrieved from http://www.sodebras. com.br/ edicoes/N117.pdf

DATASUS - Departamento de Informática do Sistema Único de Saúde, 2016 a. População residente Goiás - 1980-2012. Retrieved from http://datasus.saude. gov.br/

DATASUS - Departamento de Informática do Sistema Único de Saúde, 2016 b. População residente Goiás - 2012-2015. Retrieved from http://datasus.saude. gov.br/ 
EC - European Commission, 2011. Roadmap to a Resource Efficient Europe. Communication from the Commission to the European Parliament, the Council, the European Economic and Social Committee and the Committee of the Regions. Brussels. Retrieved from http://eurlex.europa.eu/legal-content $/ \mathrm{EN} / \mathrm{TXT} /$ ?uri $=\mathrm{CELEX} \%$ 3A52011DC0571

Feo, G. De, Malvano, C., 2009. The use of LCA in selecting the best MSW management system. Waste Management, 29(6), 1901-1915. doi.org/10.1016/j.wasman.2008.12.021

Figueiredo, F.F., 2012. Similitudes na gestão dos resíduos sólidos urbanos em países centrais e periférico. Revista Bibliográfica de Geografía Y Ciencias Sociales, 17. Retrieved from http://www.ub.edu/geocrit/b3w-975.htm

Godecke, M.V., Naime, R.H., Figueiredo, J.A.S., 2013. O consumismo e a geração de resíduos sólidos urbanos no Brasil. Revista Eletrônica em Gestão, Educação e Tecnologia Ambiental, 8(8), 1700-1712. doi.org/ 10.5902/ 223611706380

Guerrero, L.A., Maas, G., Hogland, W., 2013. Solid waste management challenges for cities in developing countries. Waste Management, 33(1), 220-232. doi.org/10.1016/j.wasman.2012.09.008

Hannan, M.A., Al Mamun, M.A., Hussain, A., Basri, H., Begum, R. A., 2015. A review on technologies and their usage in solid waste monitoring and management systems: Issues and challenges. Waste Management, 43, 509-523. doi.org/10.1016/j.wasman.2015.05.033

IBGE - Instituto Brasileiro de Geografia e Estatística, 2013. Projeção da População das Unidades da Federação por sexo e idade: 2000-2030. Retrieved March 8, 2016, from http://www.ibge.gov.br/home/ estatistica/populacao/ projecao_da_populacao/2013/default.shtm

IBGE - Instituto Brasileiro de Geografia e Estatística, 2015. Área territorial brasileira. Retrieved April 17, 2016, from http://www.ibge.gov.br/home/geociencias/cartografia/def ault_territ_area.shtm

IBGE - Instituto Brasileiro de Geografia e Estatística, 2016a. Cidades@Goiás. Retrieved May 4, 2016, from http://cod.ibge.gov.br/1V4

IBGE - Instituto Brasileiro de Geografia e Estatística, 2016 b. Estados@ Goiás. Retrieved May 4, 2016, from http://www.ibge.gov.br/estadosat/perfil.php?sigla=go

IBGE - Instituto Brasileiro de Geografia e Estatística, 2016 c. Estados@ Tocantins. Retrieved May 4, 2016, from http://www.ibge.gov.br/estadosat/perfil.php?sigla=to

IBGE - Instituto Brasileiro de Geografia e Estatística, 2016 d. Estimativa da população residente nos municípios brasileiros com data de referência em 1o de julho de 2015. Retrieved from http://www.ibge.gov.br/home/estatistica/populacao/ estimativa2015/estimativa_dou.shtm

IMB - Instituto Mauro Borges de Estatísticas e Estudos Socioeconômicos, 2014. Regiões de planejamento 2013 Estado de Goiás. Retrieved May 23, 2017, from http://www.imb.go.gov.br/down/regplan2013.pdf

Kontos, T.D., Komilis, D.P., Halvadakis, C.P., 2005. Siting MSW landfills with a spatial multiple criteria analysis methodology.
RESEARCH PAPER
Management,
25(8),
$818-832$.
doi.org/10.1016/j.wasman.2005.04.002

Lavee, D., Nardiya, S., 2013. A cost evaluation method for transferring municipalities to solid waste source-separated system. Waste Management, 33(5), 1064-1072. doi.org/10.1016/j.wasman.2013.01.026

Malakahmad, A., Abualqumboz, M.S., Kutty, S.R.M., Abunama, T.J., 2017. Assessment of carbon footprint emissions and environmental concerns of solid waste treatment and disposal techniques; case study of Malaysia. Waste Management, (September). doi.org/10.1016/ j.wasman.2017.08.044

Marchi, C.M.D.F., 2015. Novas perspectivas na gestão do saneamento: apresentação de um modelo de destinação final de resíduos sólidos urbanos. Revista Brasileira de Gestão Urbana, 7(1), 91-105. doi.org/10.1590/2175-3369.007.001.A006

Marques, J.A.A. de S., Sousa, J.J. de O., 2008. Hidráulica Urbana Sistemas de abastecimento de água e de drenagem de águas residuais. Imprensa da Universidade de Coimbra.

NURSOL/UFG - Núcleo de Resíduos Sólidos e Líquidos da Universidade Federal de Goiás, 2014. Estudo da integração da logística da coleta seletiva (Produto 5). Goiânia/GO.

Pereira, A.A., Brito, E.A.C., Capel, H.S.F., 2009. Goiás e a vinda da família real para o Brasil - 200 anos. Goiânia/GO: Biblioteca Municipal Marietta Telles Machado.

Piñas, J.A.V., Venturini, O. J., Lora, E.E.S., Oliveira, M.A. de, Roalcaba, O.D.C., 2016. Aterros sanitários para geração de energia elétrica a partir da produção de biogás no Brasil: comparação dos modelos LandGEM (EPA) e Biogás (Cetesb). Revista Brasileira de Estudos de População, 33(1), 175-188. doi.org/10.20947/S0102-309820160009

Pires, A., Martinhab.o, G., Chang, N.-B., 2011. Solid waste management in European countries: a review of systems analysis techniques. Journal of Environmental Management, 92(4), 1033-1050. doi.org/10.1016/j.jenvman.2010.11.024

Qasim, S.R., 1999. Wastewater treatment plants. Planning, design and operations (2a). Lancaster PA: Technomic Publishers.

Rios-Neto, E.L.G., Riani, J. de L.R., 2004. Introdução à demografia da educação. Associação Brasileira de Estudos Populacionais - ABEP.

Rodrigues, J.C., Santos, R.F.B. dos., 2015. A geografia política do estado do Tocantins: análise da criação/emancipação de municípios. Geographia Opportuno Tempore, 2(1), 21-35. Retrieved from http://www.uel.br/revistas/uel/index.php/ Geographia/article/view/22694

SECIMA/GO - Secretaria de Meio Ambiente Recursos Hídricos Infraestrutura Cidades e Assuntos Metropolitanos, 2015. Nota técnica - aterros sanitários. Goiânia/GO, Brasil.

SEGPLAN - Secretaria de Estado de Gestão e Planejamento, and SEPIN - Superintendência de Estatística Pesquisa e Informações Socioeconômicas, 2011. Dinâmica populacional de Goiás: uma análise do Censo 2010 do IBGE. Goiânia. Retrieved from http://www.imb.go.gov.br/down/dinamica_populacional _de_goias.pdf

Souza, D. da S., 2011. A distribuição populacional de Goiás frente aos dados do censo demográfico 2010. Conjuntura Econômica Goiana, 18 (Outubro), 32-43. Retrieved from http://www.imb.go.gov.br/pub/conj/conj18/artigo03.pdf 
Tchobanoglous, G., Theisen, H., Vigil, S. A., 1993. Integrated solid waste management - Engineering principles and management issues. New York: McGraw-Hill.
World Bank, 2012. What a Waste. A Global Review of Solid Waste Management. Urban Development and Local Government Unit. Washington. Retrieved from http://www.ncbi. nlm.nih.gov/pubmed/25270340 